\title{
The governance of justice and internal security in Scotland: Between the Scottish independence referendum and British decisions on the $\mathrm{EU}$
}

Christian Kaunert*, Sarah Léonard, Stephen Rozée and Helena Carrapiço

School of Humanities, University of Dundee, Tower Building, DD1 4HN, Scotland, United Kingdom

*Corresponding author. Email: c.kaunert@dundee.ac.uk

This article examines how the governance of justice and internal security in Scotland could be affected by the outcome of the Scottish independence referendum in September 2014. It argues that it is currently impossible to equate a specific result in the referendum with a given outcome for the governance of justice and internal security in Scotland. This is because of the complexities of the current arrangements in that policy area and the existence of several changes that presently affect them and are outside the control of the government and of the people of Scotland. This article also identifies an important paradox. In the policy domain of justice and internal security, a 'no' vote could, in a specific set of circumstances, actually lead to more changes than a victory of the 'yes' camp.

Keywords: Area of Freedom, Security and Justice; Independence Referendum; Justice and Home Affairs; Opt-out; Scotland.

In August 2009, Scottish Cabinet Secretary for Justice Kenny MacAskill ordered the release from prison on compassionate grounds of Abdelbaset al-Megrahi, who had been convicted in 
2001 of the bomb attack on Pan Am Flight 103 on 21 December 1988 (also known as the 'Lockerbie bombing'). This decision proved controversial, not only in Scotland, but also in the rest of the United Kingdom (UK) and beyond, and led to a special sitting of the Scottish Parliament to allow Members of the Scottish Parliament (MSPs) to question the Scottish Justice Secretary. In April 2013, the Police Service of Scotland (or 'Police Scotland') was established following the adoption of the Police and Fire Reform (Scotland) Act 2012. This represented a major change in the organisation of policing in Scotland. In a move confirming the existence of 'divergent tides of police reform' across the UK (Fyfe and Henry 2012, p. 176), eight territorial police forces and the Scottish Crime and Drug Enforcement Agency were merged into one single organisation. These two examples emphasise the existence of a phenomenon that is often ignored or misunderstood, even within the UK, namely the peculiar situation of Scotland in the UK's internal security architecture. Whilst it had retained a distinct legal system following the adoption of the Acts of Union in 1707, Scotland saw its parliament restored in 1999. The Scottish Parliament was given legislative competences over a range of so-called 'devolved' matters, including the environment, rural affairs, housing, health, education and justice. In these policy areas, legislation may, and in practice does, differ from that adopted by Westminster.

The peculiarity of the Scottish position is further reinforced by the fact that Scotland is - at least, as of 2014 - part of a state, i.e. the UK, which is a member of the European Union (EU), but without participating in all its policies. In particular, the UK does not fully participate in the increasingly significant field of EU Justice and Home Affairs (JHA), known nowadays as the EU's Area of Freedom, Security and Justice (AFSJ) - an umbrella term for EU cooperation on policing, criminal justice, counter-terrorism, border management, asylum and migration (see Balzacq and Carrera 2006, Kaunert 2010c). Over the past decade, the 
AFSJ has arguably become the fastest growing policy field at the EU level. However, the UK has not adopted the same route of participation in the AFSJ as the overwhelming majority of Member States. Instead, it has chosen a model of selective participation in this policy area, whereby it chooses the pieces of legislation in which it wishes to participate. Such a strategy has enabled the UK to avoid being systematically subject to qualified majority voting and to the jurisdiction of the Court of Justice of the EU in policy areas where it considers that its national sovereignty could be threatened (Peers 2012). Nevertheless, the UK has chosen to opt into parts of the JHA acquis, including measures regarding irregular migration, asylum, criminal justice, policing, judicial cooperation and counter-terrorism (Hinarejos et al. 2012). All these opt-in and opt-out decisions currently bind Scotland as well, as it is part of the UK.

However, the current model of justice and internal security governance in Scotland could be significantly altered by the result of the upcoming independence referendum. On 18 September 2014, the people of Scotland will be asked whether Scotland should be an independent country. This referendum could have a very significant impact, depending on its result. If Scotland were to become independent, then it would have the capacity to develop its own policies with regard to all justice and internal security issues, which could be significantly different from those adopted at Westminster. However, this may not be the only effect of independence. At the moment, it is not entirely clear what the impact of Scottish independence would be on EU membership. Although this is strongly contested by some observers, it is not entirely impossible that Scotland may find itself, at least temporarily, outside of the EU. In February 2014, the outgoing President of the European Commission, José Manuel Barroso, even went as far as declaring that it would be 'difficult, if not impossible' for an independent Scotland to become a member of the EU (Guardian 2014b). The absence of EU membership would have a significant impact on the justice and internal 
security policies of Scotland. In addition, even if there was no majority in favour of independence, a strong result for the 'yes' camp could lead to further devolution of competences to Scotland, possibly in the domain of justice and internal security.

Given the possibility of all these important changes, it is therefore surprising that relatively little attention has been given to justice and internal security matters in the referendum debates so far. This is notably evident when considering all the reports and white papers on the future of Scotland released by the Scottish government. Political debates have mainly focused on socio-economic issues, such as welfare, employment and the North Sea gas and oil revenue. When security issues have been considered, most attention has been directed towards foreign policy and defence matters. In particular, the future of the Trident nuclear submarines currently based on the Gare Loch has been at the heart of intense debates. Academic research has also tended to focus on these same issues at the expense of justice and internal security. As a result, there has been little reflection on how the governance of justice and internal security in Scotland may be affected by the result of the upcoming Scottish independence referendum, although its impact could be very significant. Against this backdrop, the main aim of this article is to examine how the governance of justice and internal security in Scotland could be affected by the outcome of the Scottish independence referendum in September 2014.

This article argues that it is currently impossible to equate a specific result in the referendum with a given outcome for the governance of justice and internal security in Scotland. This is because of the complexities of the current arrangements in that policy area and the changes that presently affect them and that are outside the control of the government and of the people of Scotland, as will be shown later in this article. To a certain extent, this can be said of most 
policy areas, as the debates in the run-up to the referendum have highlighted that there are still question marks over a series of important issues. However, this article shows that uncertainty is particularly high when it comes to the governance of justice and internal security, because this policy area is uniquely characterised by the combination of significant devolved competences to Scotland, the granting of important competences to the EU, and the peculiar position of the UK within the AFSJ with its various 'opt-ins' and 'opt-outs'. Therefore, it is not possible to identify two main outcomes depending on whether the result of the referendum is 'yes' or 'no'. There is actually a range of possible scenarios because of the existence of parallel debates at the UK level on the extent of the UK's participation in the AFSJ (that is, the issue of the 'JHA block opt-out') and even on its actual membership of the EU.

For this purpose, this article is structured as follows. Firstly, it is necessary to present the current organisation of competences over justice and internal security issues in Scotland. This is a crucial step in the analysis because this topic is both extremely complex and, as demonstrated in the next section, largely neglected in the existing literature. Of particular interest here are two distinct issues, namely the devolution of some competences to Scotland within the UK and the UK's membership of the EU, albeit with a peculiar position within the AFSJ. Moreover, it is argued that these issues are best analysed using a multilevel governance (MLG) analytical framework, given its emphasis on the location of various competences within a given policy area at different levels of government, namely, in this case, the Scottish, British and EU levels. Once the multilevel governance of justice and internal security issues in Scotland has been presented, it is then possible to analyse the impact of the Scottish independence referendum over this policy area. The following two sections highlight two other events, the outcomes of which could interact with those of the 
Scottish independence referendum, namely the decision of the British government regarding the JHA block opt-out and a possible referendum on the UK's membership of the EU in the years to come. The article concludes by identifying an important paradox at the heart of the debates in the run-up to the Scottish independence referendum.

\section{Scotland and the UK within the AFSJ}

Given the increasing number of competences that have been granted to the EU in the field of justice and internal security in recent years, it is necessary to locate the governance of justice and internal security in Scotland within its broader EU context. The AFSJ has seen very significant policy developments since the late 1990s (Kaunert 2010c). As a result of the major treaty revisions decided in Maastricht, Amsterdam, Nice, and more recently Lisbon, as well as increased political impetus given at the European Council meetings in Tampere (1999), The Hague (2004), and Stockholm (2009), the AFSJ is arguably the most dynamic policy fields in European integration at the moment.

The rapid development of the AFSJ in recent years has led to a considerable expansion of the scholarly literature on this topic, including legal analyses (Walker 2004, Peers, 2006, 2012). Most scholars have argued that the development of the AFSJ has been mainly driven by security concerns and that, as a result, freedom, justice, as well as human rights, have been neglected, if not damaged in some instances (Baldaccini et al. 2007, Balzacq and Carrera 2006, Huysmans 2006, Guild and Geyer 2008, van Munster 2009, Bigo et al. 2010). Other works have focused on examining EU policy developments in the field of internal security using Security Studies frameworks and concepts, such as 'homeland security' (Kaunert et al. 2012) and 'comprehensive security' (Kaunert and Zwolski 2013). Some literature has also emerged on the external dimension of the EU internal security policies. It has particularly 
emphasised how the EU has sought and sometimes managed to influence the internal security policies of third states, in particular in its neighbourhood (Balzacq 2009, Trauner and Carrapiço 2012).

The literature on the AFSJ in general has also been complemented by more specialised works, which have focused on specific aspects or policy dimensions of the AFSJ. In that respect, the EU counter-terrorism policy has attracted a particularly high level of attention (Spence 2007, Eckes 2009, Bures 2011, Argomaniz 2011, Kaunert and Léonard 2011, Léonard and Kaunert 2012, Kaunert et al. 2012, Bossong 2012, MacKenzie et al. 2013). In contrast, institutional issues have overall been less studied, apart from some early works focusing on the legal intricacies of the then 'third pillar' (e.g. Bieber and Monar 1995), Kaunert's works (Kaunert 2005, 2007, 2010a, 2010b, 2010c, Kaunert and Della Giovanna 2010) on the role of the European Commission and the Secretariat of the Council in the AFSJ, as well as the emerging literature on the European Parliament's role (Ripoll Servent 2010, 2011, 2013, Ripoll Servent and MacKenzie 2011, 2012).

In contrast to the burgeoning literature on these issues, political scientists have, with the notable exception of Adler-Nissen $(2009,2011,2014)$, given only limited attention to the peculiar position of some states within the AFSJ, namely the UK, Ireland and Denmark. Those have chosen not to engage fully with the current EU integration process in the field of justice and internal security, which has led to the development of 'differentiated integration' (Adler-Nissen 2009) or 'variable geometry' (Usher 1997) in JHA (now the AFSJ). Although there are variations amongst these three states, the main reason underpinning the stance of their government is that they wish to maintain control over matters that they view as being of key importance to their national sovereignty, in particular immigration, asylum, and security 
policies (Wallace 1997). In the specific case of the UK, the government considers that not all EU justice and internal security measures favour its national interests, which have been constructed around the protection of its common law system and its unique geographical characteristics (Cameron 2013, Home Office 2013a). Successive British governments have therefore been opposed to joining the Schengen zone, for example, because they have continued to emphasise border controls rather than internal security measures, such as the mandatory registration of all national and non-national residents with the police, which is in force in many other EU Member States. Finally, it is important to note that the position of the UK within the AFSJ is made even more peculiar by the existence of three legal systems namely one each for England and Wales, Scotland and Northern Ireland -, as well as the ongoing process of devolution that has seen the transfer of several functions to national parliaments or assemblies, namely the Scottish Parliament, the National Assembly for Wales and the Northern Ireland Assembly. Again, this is a peculiarity of the UK's position within the AFSJ that has been largely overlooked in the scholarly literature to date.

\section{Justice and internal security in Scotland and multi-level governance}

The most adequate way to analyse the governance of justice and internal security in Scotland is arguably through the use of an MLG framework, which is best suited to capture all the nuances of such a complex situation. MLG refers to the idea that there has been a general and gradual shift from state-centralised power to the existence of multiple centres of power, including supranational, regional, and local centres (Hooghe and Marks 2001). Given the devolution of certain functions to Scotland and the decision to grant the EU increasing competences in the field of justice and internal security, albeit with specific restrictions when it comes to some Member States such as the UK, it is argued here that an MLG framework is particularly adequate to shed light on the evolution of justice and internal security governance 
in Scotland. On the one hand, it is important to include the EU level in the analysis, as the EU now exercises some important competences over certain aspects of justice and internal security. On the other hand, it is equally important to also consider the UK level, as the British government and Parliament have retained some important competences in justice and internal security. They thereby play an important role as intermediary between Scotland and the EU, as will be shown later in this article when analysing the current debates on the JHA block opt-out.

Over the past twenty years, the academic literature on MLG has flourished, which has notably led to various refinements and re-interpretations of the concept (see Stephenson 2013). MLG has been mainly used as a framework for analysing the decentralisation of political systems and their policy-making mechanisms (e.g. Conzelmann and Smith 2008, Cairney 2012, Levi-Faur 2012, Kohler-Koch and Larat 2009). It has promoted an understanding of the EU as a dynamic polity, which is distinct from international organisations and is characterised to a significant extent by the same features as a domestic political system (Bache and Flinders 2004, Hix 1994). This has led to the development of a more dynamic and complex view of policy-making processes, which are seen as being characterised by power diffusion through negotiation from a centralised state to a large number of bodies at different hierarchical levels - both above and below the national level (Hooghe and Marks 2010, Richards and Smith 2004, Kohler-Koch 1998).

The remainder of this section examines the governance of justice and internal security matters in Scotland through the lenses of MLG. It highlights the vertical process of power diffusion (Marks 1993, Marks and Hooghe 2004) that has led to the current distribution of competences over the various aspects of justice and internal security between the Scottish, 
British and EU levels. It also examines the institutional arrangements governing the relations between the different levels.

\section{The Scottish jurisdictional level}

The location of some justice and internal security competences at the Scottish jurisdictional level derives from the Scotland Act 1998, although it is important to note that Scotland had retained a distinct legal system following the adoption of the Acts of Union in 1707. Schedule 5 of the Scotland Act 1998 lists all matters reserved to the UK Parliament; the matters that are not mentioned in this section are devolved to the Scottish Parliament (see Cairney 2006, Scott 2011). In the field of justice and internal security, the devolved areas include most aspects of criminal law and civil law, the prosecution system, the court system and the police. Since devolution, major reviews of different parts of the criminal justice system have taken place, resulting in new primary and secondary legislation (Eski et al. 2011, pp. 10-13). As a result, one has witnessed several significant changes to Scottish criminal justice, such as the creation of over twenty new criminal justice bodies and partnerships. Those include eight Community Justice Authorities, which have been created in order to reduce re-offending, as well as national agencies, such as the Risk Management Authority, which aims to monitor serious violent and sexual offenders. New offences have also been created since devolution following the adoption of several pieces of legislation, including the Antisocial Behaviour etc. (Scotland) Act 2004 and the Domestic Abuse Act (Scotland) 2011.

With regard to civil justice, Scotland possesses a complex network of courts that is distinct from the rest of the UK. The Court of Session is the Supreme Court in Scotland and is responsible for the initial consideration of civil cases, as well as their appeal. Its decisions can only be appealed with recourse to the House of Lords. The Court of Session has an Inner 
House and an Outer House. The former acts as an appeal court, whereas the latter is composed of 22 Lords Ordinary who mainly hear cases regarding tort, contract, commercial law and judicial reviews. However, the majority of cases are heard through a wide network of local courts known as 'Sheriff Courts'. There are currently 49 such courts, which essentially deal with debt, claims for compensation, contract disputes, divorce, family law, and antisocial behaviour. Scotland also has Justice of Peace Courts and Tribunals. Justice of Peace Courts are composed of lay magistrates who hear specific types of disputes, such as those concerning employment and mental health. There are three types of tribunals in Scotland: those that deal with devolved matters with Scottish jurisdiction and structures, those that deal with reserved matters, but also have Scottish jurisdiction and structures, and those that deal with reserved matters and have British jurisdiction and structures.

\section{The British jurisdictional level}

Whilst some matters have been devolved to Scotland, Schedule 5 of the Scotland Act 1998 specifies a series of matters that are reserved to the UK Parliament ('reserved matters') and on which the Scottish Parliament cannot therefore legislate. Those include various matters that belong to, or are at least related to, the realm of internal security, namely defence; money laundering; the misuse of drugs; firearms; control of weapons; extradition; data protection; immigration and nationality, including asylum, the issue of travel documents and free movement of persons; as well as national security, the interception of communications, official secrets and terrorism. Importantly, foreign affairs, including the relations with the EU, are also a reserved matter.

There are two other important issues that should be mentioned when considering the relations between the Scottish and British levels in the field of justice and internal security. The first is 
the 'Sewel Convention'. Section 28 (7) of the Scotland Act 1998 stipulates that the British Parliament is not prevented from legislating on matters that have been devolved. However, under the constitutional convention known as the 'Sewel Convention', the British Parliament does not normally legislate on matters that have been devolved to Scotland without the consent of the Scottish Parliament. The second important issue in the relations between the British and Scottish levels is the existence of Legislative Consent Motions, formerly known as 'Sewel Motions'. Those can be passed by the Scottish Parliament in order to allow the British Parliament to legislate for the whole of the UK if it is considered 'sensible and advantageous for Scotland' to do so (Sewel Convention Introduction, section 3). Thus, when it comes to the division of competences between the Scottish and British levels, devolution has led to the inter-mixing of responsibilities over certain matters, or 'blurring of competences', across the two jurisdictional levels, rather than a clear separation of functions (John et al. 2011, p. 1066, see also ke; et al. 2003, p. 131). Legislative Consent Motions have been passed on several occasions since 1999 including in the cases of the Criminal Justice and Court Services Bill; the International Criminal Court Bill; the Anti-Terrorism, Crime and Security Bill; the Crime (International Co-operation) Bill; the Extradition Bill; the Serious Organised Crime and Police Bill; the Police and Justice Bill; the Tribunals, Courts and Enforcement Bill; the Serious Crime Bill; the Policing and Crime Bill; and the Terrorism Prevention and Investigation Bill (Scottish Government 2012).

\section{The EU jurisdictional level}

The governance of justice and internal security matters in Scotland is also significantly influenced by developments at the EU level, since the UK has been a Member State of the EU since 1973. After several years of intergovernmental cooperation outside of the framework of the European Community, notably within the Trevi group, the EU was granted 
its first competences on internal security and justice matters by the Treaty of Maastricht. Article K.1 of Title VI of the Treaty on European Union (1993) stated that '[for] the purpose of achieving the objectives of the Union, in particular the freedom of movement of persons, and without prejudice to the powers of the European Community, Member states shall regard the following areas as matters of common interest (...)'. There were nine areas of common interest, namely (1) asylum policy; (2) external border control; (3) immigration (entry, circulation, stay and fight against illegal immigration); (4) fight against drugs and (5) against international crime; (6) judicial cooperation in civil matters and (7) in criminal matters; (8) customs cooperation; and (9) police cooperation. However, the new treaty placed these issues in the separate so-called 'third pillar' of Justice and Home Affairs (JHA) (alongside the European Community (first pillar) and the Common Foreign and Security Policy (second pillar)). Cooperation on these matters was therefore formalised, but continued mainly on an intergovernmental basis as previously (Geddes 2000, p. 86). As a result, policy progress under the Treaty of Maastricht remained limited (Uçarer 2001, p. 6).

In 1999, the Treaty of Amsterdam entered into force and gave a strong impetus to the development of JHA policies, which were re-labelled the 'Area of Freedom, Security and Justice' (AFSJ). This change was not merely cosmetic, but signalled the rise in prominence of justice and internal security cooperation in the EU. Whereas JHA cooperation had concerned 'matters of common interest', which had to be regarded as such by Member States '[for] the purposes of achieving the objectives of the Union' (Article K.1 TEU), the realisation of the AFSJ was identified as an objective in its own right. The Treaty of Amsterdam stipulated that 'the Union's objective shall be to provide citizens with a high level of safety within an area of freedom, security and justice by developing common action among the member states (...)'. In order to achieve this ambitious plan, significant changes were made to the institutional 
arrangements governing JHA matters, which resulted in a partial communitarisation of the third pillar. Controls on the external borders, asylum, immigration and judicial cooperation on civil matters were all transferred to the first pillar. Nevertheless, the incorporation of these areas into the first pillar was to take place gradually, although it had to be completed within five years of the entry into force of the Treaty of Amsterdam. As for police and judicial cooperation in criminal matters, they were to remain in the third pillar. This partial communitarisation was seen by the British government as potentially threatening national sovereignty. This led to the adoption of various protocols that were attached to the Treaty of Amsterdam, including those establishing the opt-ins and opt-outs enjoyed by the UK, which will be examined in greater detail later in this article.

Ten years later, the Treaty of Lisbon entered into force on 1 December 2009. It has reorganised all EU treaty provisions into two separate treaties, namely the Treaty on European Union (TEU) and the Treaty on the Functioning of the European Union (TFEU). It has also created a simplified decision-making procedure, as the pillar structure has been formally abolished. The communitarisation of criminal justice and policing matters has also been deepened, although it is still not fully complete because of provisions establishing 'emergency brakes' and 'accelerators' (Kaunert 2010c). Title V of the TFEU ('Area of Freedom, Security and Justice') lays down the EU's specific objectives for each policy dimension of the AFSJ.

Regarding the relationship between EU law and Scottish law, the Scotland Act 1998, in its section 29, lays down that '[an] Act of the Scottish Parliament is not law so far as any provision of the Act is outside the legislative competence of the Parliament', whilst specifying in clause 2 (d) that this includes any instance where an Act of the Scottish 
Parliament should be incompatible with EU law, in accordance with the Treaty of Lisbon which entered into force on 1 December 2009. Similarly, EU law takes precedence over the domestic law of Member States, which means that UK law may not be incompatible with EU law either.

\section{Institutional arrangements governing the relations between the different levels}

The issues of the representation of the Scottish interests in EU negotiations and of their inclusion in the definition of the British positions in Brussels have proved rather controversial. Surprisingly, they have received little academic attention to date, with the notable exception of the works by Bulmer et al. (2002) and Palmer (2008), whilst reports by the Scottish and British governments on this topic have tended to present contrasting views and to favour particular political agendas.

In Westminster, it is often emphasised that, while foreign policy is currently a reserved matter for the UK, there is a Memorandum of Understanding between the British and Scottish governments that includes a Concordat on the Co-ordination of European Policy Issues (House of Commons Foreign Affairs Committee 2013, p. 35). This non-binding document addresses the following issues; provision of information, formulation of British policy, attendance at Councils of Ministers and related meetings, as well as infraction procedures (Palmer 2008, p. 69). The Concordat provides for the UK to take the leading role in foreign affairs 'with input from Scottish Ministers, as appropriate, where there are particular Scottish interests at stake' (House of Commons Foreign Affairs Committee 2013, p. 35). In addition, the Scottish Representation Office in Brussels aims to ensure that Scottish interests are voiced in the EU arena (Engel and Parks 2012, p. 3). 
However, the view from Scotland is somewhat different. According to the Scottish government (2013, p. 458), 'Scotland currently has a limited voice in Europe'. In a 2007 Scottish Government publication on future issues relating to devolution and independence, it is emphasised that, as Scotland remains a constituent part of the UK, rather than an EU Member State in its own right, UK Ministers usually lead in EU negotiations in practice. UK Ministers should be required to represent the variety of interests and communities across Britain, as well as being accountable to the Parliament at Westminster (Scottish Government 2007, p. 16). The publication also suggests that a greater role in leading negotiations where vital Scottish interests are at stake should be granted to Scottish representatives and that the British Government should agree for the Scottish Government to have a decisive - or, at least, greater - say in formulating the UK's negotiating position prior to and during EU negotiations (Scottish Government 2007, p. 16). Another publication of the Scottish government in 2011 has argued that the current arrangements are not sufficient to answer Scotland's needs and that independence and Scottish membership of the EU would protect Scotland's interests and would allow Scotland to provide input into global issues (Scottish Government 2011; see also House of Commons Foreign Affairs Committee 2013, pp. 35-36). The Scottish government has also highlighted what it perceives as a lack of Scottish influence over UK policies and dealings with Brussels in several specific areas that are highly important to Scotland, such as fisheries, renewable energy and marine legislation (Guardian 2011). This is because, whilst the Scottish government is allowed to contribute to Westminster discussions about EU proposals that concern devolved matters, the British government is actually not obliged to incorporate the views of the Scottish government into its positions for EU-level negotiations (Scottish Government 2013b, p. 458). 
Having examined how the governance of justice and internal security in Scotland is currently organised across three levels (Scotland, UK, EU), it is now possible to consider how this system of governance could be significantly influenced by the result of the Scottish independence referendum of 18 September 2014.

\section{The Scottish independence referendum of 2014}

Justice and internal security matters have not featured prominently in the debates in the runup to the Scottish referendum. There has been significantly more emphasis on the economy, which has also been shown to be the issue that most heavily influence a 'yes' or a 'no' vote (Guardian 2014a). This general lack of attention given to justice and internal security issues may also be explained by the fact that a 'yes' vote in the referendum would not lead to momentous change in this policy area. As previously noted, several justice and internal security matters have already been devolved to Scotland. In contrast, certain matters are reserved to the UK, such as counter-terrorism and legislation on the misuse of drugs. The Scottish government has suggested that, should these reserved matters become Scottish competences, as would be the case after independence, new legislation could be adopted in order to better address the actual security threats faced by Scotland or to make policy measures more consistent with the Scottish criminal justice system (Scottish Government 2007, p. 11). In particular, it has identified the following issues as priorities in an independent Scotland: firearms, road traffic offences and drink driving, gambling and drugs (Scottish Government 2013b, p. 258). It has also hinted at a more socio-economic approach to crime, by emphasising the possibilities offered by independence to use employment, housing, education and other welfare measures to tackle deprivation and crime in communities (Scottish Government 2013b, p. 258). However, to date, the Scottish government has allowed the British government to legislate upon a significant range of devolved policing and criminal 
justice matters by way of Legislative Consent Motions (Scottish Government 2012), as explained before. As such decisions entail an implicit recognition that it is advantageous for Scotland to see the adoption of UK-wide measures on a series of issues, this could be interpreted by some as weakening the case for independence, at least as far as justice and internal security matters are concerned. Furthermore, an independent review of policing published by the Scottish government has found that chief police officers strongly felt that tackling some issues, such as terrorism, required a UK-wide approach (Scottish Government 2009, p. 60). Therefore, it is unclear to what precise extent Scotland would gain by receiving additional competences in justice and internal security following independence. This may explain why the Scottish government has not drawn much attention to these issues in its promotion of a 'yes' vote at the referendum.

At the same time, the British government has, for its part, decided to highlight certain potential burdens relating to justice and internal security matters for Scotland if it were to become an independent country. Amongst those are the costs and difficulties of creating Scottish security facilities, such as an independent intelligence service, as well as the challenge of gaining trust and cooperation from the intelligence agencies of other countries. David Lidington, a Foreign Office minister, has claimed that Scotland would face billions of pounds in costs in order to develop new security facilities and to set up secure communications for its intelligence agencies before it could persuade MI5, MI6, the CIA and other allies to begin to cooperate. According to Lidington, '[it] would require all members of that community to be satisfied both that it was to their overall advantage in terms of intelligence gathering and sharing [...] and most importantly for them, to have confidence in the ability of an independent Scotland's safeguarding of that information' (The Guardian, 2013). In the same hearing at the foreign affairs committee, Tory MP Rory Stewart, a former 
army officer and Foreign Office diplomat, also claimed that the costs of setting up a secure intelligence infrastructure could run into billions of pounds (The Guardian 2013). In response to these criticisms, the Scottish government has emphasised that it does not intend to replicate the three UK Security and Intelligence Agencies (MI5, MI6 and GCHQ), since '[i]ndependence offers an opportunity to build a new model for such work, that is fit for the $21^{\text {st }}$ century and provides a proportionate means of ensuring Scotland's national security' (Scottish Government 2013b, p. 488). The Scottish government therefore intends to establish a single security and intelligence agency for Scotland, should it become independent.

With regard to policing, Scottish Cabinet Secretary for Justice Kenny MacAskill gave assurances at the 2013 Scottish Police Federation Annual Conference that an independent Scotland would continue with the same cross-border police cooperation with the rest of the UK (rUK) that it currently enjoys (Scottish Government 2013a). This was reaffirmed in the Scottish government's Scotland's Future publication. This highlighted that '[there] are existing well-established arrangements to ensure effective cross-border co-operation between Police Scotland and forces in the rest of the UK [and that it] will be in the shared interests of Scotland and the rest of the UK to ensure that these practical arrangements continue following independence' (Scottish Government 2013b, p. 503).

The issue of border controls has been another source of contention between the British and Scottish governments. On several occasions, the British government has warned that Scottish independence would entail the establishment of border controls between Scotland and England. In May 2012, British Home Secretary Theresa May declared that '[if] there was a separate Scotland there could very well be some sort of border check' (BBC News 2012b). By March 2014, her discourse on this point had become less tentative as she argued that, 
should Scotland become independent, '[an] international border would be created where one does not currently exist. This would have implications for people travelling to visit family, go on holiday or do business, and for our economies more generally. [...] So that would mean border controls between a separate Scotland and the United Kingdom. Passport checks to visit friends and relatives' (Guardian 2014c). This scenario has been strongly disputed by the Scottish government. It has announced that an independent Scotland would remain in the Common Travel Area, which has existed for decades between the UK, Ireland, the Isle of Man and the Channel Islands (Scottish Government 2013b, p. 456). As a result, still according to the Scottish government, there would not be any border controls between England and Scotland.

On this basis, what are the potential outcomes of the Scottish independence referendum for the governance of internal security and justice in Scotland? This is a complex question because the referendum has both direct and indirect implications for this policy field, as will be later seen. First of all, if the referendum were to yield a 'no' result and Scotland were to remain part of the UK, most justice and internal security matters currently reserved to the UK would be likely to remain reserved in the near future. The British government would therefore continue to exercise very significant power over certain aspects of the governance of justice and internal security in Scotland (Scottish Government 2009, p. 60).

In addition, should Scotland remain inside the UK, the British opt-in and opt-out arrangements would continue to apply to Scotland. As foreign affairs matters are reserved to the UK government, the representation of Scottish issues and viewpoints would continue to be limited in EU negotiations. In this sense, the British jurisdictional level would continue in its role as an intermediary or 'gatekeeper' between Scotland and the EU, both in terms of 
leading decisions on opt-ins and opt-outs and formulating the UK's position on justice and home affairs matters in the EU. However, as will be discussed in greater detail in the following section, if the UK decided to use its right to a JHA block-opt out, this would immediately also apply to Scotland - despite the fact that Scotland has consistently argued against the block opt-out (Scottish Government 2013b, p. 504).

Secondly, if the independence referendum were to be won by the 'yes' camp and Scotland were to become an independent country, a number of important issues would be raised. The first of these is the matter of Scotland's membership of the EU. While the issue of an independent Scotland meeting the criteria for EU membership is unlikely to be problematic in general, some have argued that there may be a period of time where Scotland could find itself outside of the EU. For example, outgoing European Commission President José Manuel Barroso has stated that, legally, one part of an EU Member State wanting to become an independent state would have to apply for EU membership and would have to renegotiate the conditions of that membership (BBC News 2012a). However, this is a contested legal position, which many see as running contrary to the spirit of EU law and the generally pragmatic approach that the EU has taken when encountering challenges throughout its history. For example, Sir David Edward, a former European Court judge, has argued that, should Scotland become independent, then 'the EU institutions and all the Member States (including the UK as existing), would be obliged to enter into negotiations, before separation took effect, to determine the future relationship within the EU of the separate parts of the former UK and the other Member States', In his view, '[the] outcome of such negotiations, unless they failed utterly, would be agreed amendment of the existing Treaties, not a new Accession Treaty' (BBC News 2012c). Cram (2014) has also claimed that 'Scotland is unlikely to be cut off dead from the EU. There is little benefit to anyone of existing systems 
and relationships failing to operate in the interim'. From this viewpoint, should the referendum yield a 'yes' vote, Scotland would therefore remain within the EU during the transition period between the referendum and the day of independence, which would see the negotiation of various important issues, including EU membership. This is also the position of the Scottish government. It has stated that the discussions on the process to ensure the transition to independent EU membership would take place 'during the period in which Scotland remains part of the UK and by extension, part of the EU' in order to protect the rights and interests of EU businesses and citizens in Scotland (Scottish Government 2013b, p. 220).

It can therefore be concluded from this analysis that there remains many uncertainties as to what exactly the consequences of a 'yes' vote in the independence referendum would be for the governance of justice and internal security in Scotland. However, the impact of a 'no' vote is in no way clearer, as it would not necessarily entail stability and continuity. This is because, as it has already been alluded to in this section, the Scottish independence referendum is not the only factor that will influence the future of the governance of justice and internal security in Scotland. Two other crucial factors to consider are the decision of the British government regarding the JHA block opt-out and the result of a possible referendum on the UK's membership of the EU.

Other key variables: the 2014 JHA block opt-out and the possible referendum on the UK's membership of the EU

The decision that the British government is expected to take regarding the JHA block opt-out by the end of May 2014 will also have a very significant impact on the governance of justice and internal security in Scotland. Before examining this issue in greater detail, it is necessary 
to first explain what the UK's opt-ins and opt-outs in JHA policies are. As previously mentioned, the UK has always favoured a selective approach to EU cooperation on JHA that enables it to choose the specific measures in which it participates. The UK's participation in EU legislation in this specific field is governed by two protocols that are attached to the EU Treaties, namely Protocol 19 and Protocol 21. The 'Protocol on the position of the United Kingdom and Ireland in respect of the Area of Freedom, Security and Justice' (Protocol No 21) lays down that the UK shall not take part in the adoption by the Council of proposed measures pursuant to Title V of Part Three of the TFEU, which concerns visas, asylum, immigration and other policies related to the free movement of persons. However, it also entitles the UK to opt into any such measure should it wish to do so. These provisions have enabled the UK to opt into various measures, mainly concerning asylum and irregular migration, whilst deciding not to opt into measures regarding border controls and legal migration (Home Office 2013b; Adler-Nissen 2009). Recent examples of specific opt-ins include the decisions to opt into the Directive on attacks against information systems and the Passenger Name Records Directive (Ministry of Justice and the Home Office 2012). In 2012, the UK opted into 24 proposals under Protocol 21, having decided not to opt into eight proposals (Ministry of Justice and the Home Office 2013).

As for Protocol No 19 'on the Schengen acquis integrated into the framework of the European Union' (or 'Schengen Protocol'), it governs the participation of the UK in the management of free circulation and the lifting of internal borders. In general, the UK does not participate in EU legislation relating to Schengen cooperation, in particular the measures concerning border controls. However, it has requested to participate in the aspects of Schengen cooperation that are related to police and judicial cooperation in criminal matters. According to Article 5 of Protocol 19, the UK is expected to adopt any measure that is 
developed within EU police and judicial cooperation, unless it notifies the Council of its decision to opt out from a specific measure within three months of the tabling of a proposal or initiative. If the UK does not notify the Council of its decision to opt out within that timeframe, it is automatically bound by this measure. For instance, the British government decided not to opt out of the Directive on Data Protection (Ministry of Justice and the Home Office 2013).

As advantageous as it may appear, this approach of selective participation in the AFSJ also carries the risk for the UK - and indirectly for Scotland as long as it remains within the UK of being perceived as an 'awkward partner' (George 1998), which is not fully committed to the completion of the AFSJ. This is turn can negatively affect the UK's capacity to shape EU policies. Opt-out decisions, in particular, can be seen as leading to a loss of influence and a diminished role in the development of the AFSJ (Kelstrup 2006), whilst any attempt to opt into an individual measure is only successful if it is unanimously supported by the other EU Member States (House of Commons Foreign Affairs Committee 2013). Not all opt-in attempts have been successful, as evidenced by the case of the EU's external borders agency Frontex. The British government wanted to fully participate in the organisation and running of the agency, but was not allowed to do so - even after applying to the European Court of Justice - on the basis that it is not a full Schengen state (House of Lords European Union Committee 2008, pp. 22-24).

Against this backdrop, the British government announced in 2012 that it intended to exercise its right of opting out of all police and criminal justice measures and Schengen measures that remain unamended since the entry into force of the Treaty of Lisbon in December 2009. Home Office Secretary Theresa May also stated that it would then opt back only into the 
measures that are in the British national interest (BBC News 2013a). This right for the UK to exercise a block opt-out was established by Article 10 of Protocol 36 to the EU Treaties. Article 10 (1) provided for a transitional period - due to end on 1 December 2014 - before the full powers of the Commission (i.e. launching infringement proceedings) and of the Court of Justice (i.e. judicial control) apply to the acts concerning police cooperation and judicial cooperation in criminal matters (that is, the 'former third pillar acquis') that were adopted before the entry into force of the Treaty of Lisbon. Opting out of these measures (and not opting back into them) would mean that they would no longer apply to the UK. Subsequently, it would be possible for the UK to opt back into any of these measures at any time, which would entail the acceptance of the enforcement powers of the European Commission and of the jurisdiction of the Court of Justice with regard to them. Around 133 police and criminal justice measures in the former 'third pillar' of the EU are concerned by the block opt-out, including the European Arrest Warrant and the participation into Europol and Eurojust (Miller 2012). Only 35 measures have been identified as worthy of an 'opt-back-in' afterwards; those are listed in Command Paper 8671 ('Decision pursuant to Article 10 of Protocol 36 to The Treaty on the Functioning of the European Union'). In that respect, it is important to emphasise that opting back into these measures would not be automatic, as the relevant provisions of Protocols No 19 and No 21 would apply. Consequently, in the case of a Schengen measure, the decision on whether the UK may opt back into the measure would be taken by the Council with the unanimity of its members. No condition could be imposed on the UK's 'opt-back-in'. In contrast, in the case of a non-Schengen measure, the European Commission could impose conditions on the UK's 'opt-back-in' and set a time period for those to be fulfilled. 
Such a block opt-out in the JHA field would have very significant consequences for the UK as a whole, including Scotland. Although police and judicial cooperation are largely devolved issues, foreign affairs, including relations with the EU, constitute a reserved matter. This means that any decision made by the British government in that respect would automatically affect Scotland as well. As emphasised by Brady (2013, p. 6), Scotland 'has just as much at stake in EU co-operation on crime and policing as many individual member-states given the size of its population and the needs of its police in terms of internationally-related crime'. However, it appears that there has not been any significant Scottish involvement in the governmental discussions about the JHA block opt-out to date. This is aptly illustrated by this statement made by Scottish National Party Member of Parliament Pete Wishart in July 2013: 'The Home Secretary has said on several occasions that she is speaking on behalf of the whole United Kingdom when it comes to these measures, but she will know that there is great unhappiness in the Scottish Government, Police Scotland, and the whole legal profession about this opt-out. Why was there so little consultation with the Scottish Government, why did they know nothing about this until last week, (...)?' (HC Deb, 15 July 2013, c776). Thus, the possible exercise of the JHA block opt-out by the British government and all the uncertainties surrounding the 'opt-back-ins' have brought a considerable degree of instability to the governance of justice and internal security in Scotland. In addition to the question marks surrounding the opt-out and 'opt-back-in' processes, it appears that the Scottish government has not been significantly involved in a decision that highly concerns it given its devolved competences.

However, the decision of the British government on the JHA block opt-out is not the only development at the British level that could also seriously affect the governance of justice and internal security in Scotland. In the last few years, the issue of the UK's membership of the 
EU has become increasingly controversial. Faced with mounting pressure from Eurosceptics within his own party and the challenge represented by the UK Independence Party, Conservative Prime Minister David Cameron has pledged to renegotiate the UK's relationship with the EU and to put the result of these negotiations to the British public in an ‘in-out referendum' by the end of 2017 (BBC News 2013b). This would evidently depend on whether the Conservatives win a majority at the 2015 general elections. This promise of a referendum, even though it is conditional on the result of the next general elections, is another source of uncertainty for the future of justice and internal security governance in Scotland. Should there be an overall majority in the UK in favour of leaving the EU, Scotland, if it were still part of the UK at that time, could find itself outside of the EU, possibly against its will. The current Scottish government has repeatedly indicated that it does not wish Scotland to leave the EU and does not support Cameron's plans for an in-out referendum (Scottish Government 2013b, pp. 460-461). Even if Scotland were independent then, an exit of rUK from the EU would also have an impact on Scotland as the rUK's neighbour.

It can therefore be concluded that the independence referendum is definitely not the only event of importance for the future governance of justice and internal security in Scotland. Both the British government's decision on the JHA block opt-out and the possible British referendum on EU membership also have the potential to significantly influence the governance of justice and internal security in Scotland. This means that they should also be integrated as key variables in any analysis of the future development of justice and internal security governance in Scotland, alongside the result of the Scottish independence referendum. 


\section{Conclusion}

This article set out to identify the possible outcomes of the Scottish independence referendum regarding the governance of justice and internal security in Scotland. For that purpose, it began by analysing how justice and internal security matters are currently governed in Scotland. Because of the devolution of some of these matters to Scotland and the increasing competences of the EU in this area, it was argued that an MLG framework was best suited for examining justice and internal security governance in Scotland. The article subsequently analysed how internal security is governed at the Scottish, British and EU levels, as well as the arrangements for managing the relations between these three levels. In the following section, the article focused on the possible effects of the referendum by outlining the consequences of the 'no' and 'yes' results. It then highlighted that the Scottish referendum is not the only important event for the future governance of justice and internal security matters in Scotland. Two other issues could prove of crucial importance. Firstly, it will be important to see whether and, if yes, the extent to which the UK will continue to participate in JHA cooperation following the current debates on the UK's JHA block opt-out and the decision that will eventually be taken in that regard. Secondly, the very issue of the UK's continued membership of the EU may eventually be at stake should an 'in-out referendum' on EU membership be organised in the next few years.

Three main conclusions can be drawn from this analysis. First of all, the governance of justice and internal security matters in Scotland is extremely complex as competences in this area are exercised at three different levels. This governance system is rendered even more complicated by the peculiar position of the UK in the AFSJ with its various opt-ins and optouts. To make these arrangements even more convoluted, there could be significant changes to the UK's position in the AFSJ as a result of the current debates on the UK's JHA block 
opt-out. In that respect, some important questions have been left unanswered to date, most notably whether the UK would be allowed to opt back into all the EU measures that it has selected. Thus, the governance of justice and internal security in Scotland is particularly complex, notably because of its dynamic character. Secondly, it is impossible to reliably predict the impact of the Scottish referendum on the governance of justice and internal security for three main reasons. The first is that the result of the referendum is still in doubt as of early 2014 , especially as recent polls indicate that the gap between the 'yes' vote and the 'no' vote has recently narrowed (Scotsman, 2014). The second is that there are a lot of uncertainties regarding the consequences of a 'yes' vote for the position of Scotland within the EU. Whilst some argue that Scotland would not find itself outside the EU if the referendum were to yield a 'yes' vote, others state that Scotland would have to apply for EU membership, which could entail difficult negotiations. Should the latter scenario turn out to be correct, this would have a major impact on the MLG of justice and internal security in Scotland. The third reason for which it is extremely difficult to predict the impact of the independence referendum is that the result of this referendum is not the only factor determining the future of the governance of justice and internal security matters in Scotland. The referendum in Scotland is taking place amidst important debates at the UK level concerning the relationship between the UK and the EU. Of paramount importance in that respect will be the outcome of the current discussions on the UK's JHA block opt-out and, potentially, the result of an 'in-out referendum' on the UK's membership of the EU should it be organised in the near future. Those would mainly matter for Scotland if it were to remain in the UK, although they would also be of importance for Scotland even if it were independent from rUK because of its status as a neighbouring country (in the field of border controls, for example). 
Therefore, at this stage, it is impossible to distinguish only two scenarios for justice and internal security governance in Scotland after the referendum depending on whether Scotland votes 'yes' or 'no'. One can only identify the various factors that will influence the future of justice and internal security governance in Scotland, namely whether Scotland votes for independence or not, whether a 'yes' vote leads to a temporary or permanent exclusion from the EU or not, whether the UK (or potentially rUK) continues to cooperate on JHA with its EU partners, and whether, even more fundamentally, the UK (or possibly rUK) remains a Member State of the EU. Because of the many uncertainties at play and the multiple variables at hand, there is actually a large number of possible scenarios for the future of justice and internal security governance in Scotland. Depending on the outcomes of these three events (the British government's decision on the JHA block opt-out, the Scottish referendum on independence, and the British referendum on EU membership), Scotland could find itself, for example, inside the UK, but outside the EU; inside the UK, but largely outside the AFSJ; or outside the UK, but inside the EU.

To conclude, this article has identified an important paradox in the run-up to the Scottish independence referendum of September 2014. The 'no' vote has usually been presented as a vote against risk and for continuity. However, this article has shown that, in a policy domain such as justice and internal security, a 'no' vote in the Scottish independence referendum could paradoxically lead to more changes should the British government more or less drastically reconfigure its relationship with the EU. In contrast, and assuming that Scotland remains in (or re-joins) the EU, the 'yes' vote could actually ensure more continuity in the governance of justice and internal security.

\section{Funding}


Research for this article was supported by two Marie Curie Career Integration Grants within the $7^{\text {th }}$ European Community Framework Programme, which have been awarded to Christian Kaunert and Sarah Léonard respectively. Helena Carrapiço would like to acknowledge the support of the British Academy and the Royal Society, which run the Newton International Fellowships scheme.

\section{Notes on contributors}

Christian Kaunert is Professor of International Politics and Jean Monnet Chair in Justice and Home Affairs in the School of Humanities at the University of Dundee. He also holds a Marie Curie Career Integration Grant (2012-2016).

Sarah Léonard is Senior Lecturer in Politics in the School of Humanities at the University of Dundee. She also holds a Marie Curie Career Integration Grant (2013-2017).

Stephen Rozée is Lecturer in Politics in the School of Humanities at the University of Dundee.

Helena Carrapiço is a Newton International Fellow in the School of Humanities at the University of Dundee. Her current research project focuses on the United Kingdom opt-ins and opt-out strategies in the area of Justice and Home Affairs.

\section{References}

Adler-Nissen, R., 2009. Behind the scenes of differentiated integration: circumventing national opt-outs in Justice and Home Affairs. Journal of European Public Policy, 16 (1), 6290.

Adler-Nissen, R. 2011. Opting out of an ever closer union: the integration doxa and the management of sovereignty. West European Politics, 34 (5), 1092-1113. 
Adler-Nissen, R 2014. Opting Out of the European Union: Diplomacy, Sovereignty and European Integration. Cambridge: Cambridge University Press.

Argomaniz, J., 2011. The EU and Counter-terrorism: Politics, Polity and Policies after 9/11. London: Routledge.

Bache, I. and Flinders. M., eds., 2004. Multi-level Governance. Oxford: Oxford University Press.

Baldaccini, A., Guild, E. and Toner, H., eds., 2007. Whose Freedom, Security and Justice? EC Immigration and Asylum Law and Policy. Oxford: Hart.

Balzacq, T., ed. 2009. The External Dimension of EU Justice and Home Affairs: Governance, Neighbours, Security. Basingstoke: Palgrave Macmillan.

Balzacq, T. and Carrera, S., eds., 2006. Security versus Freedom? A Challenge for Europe's Future. Aldershot: Ashgate.

BBC News. 2012a. Scottish independence: EC's Barroso says new states need 'apply to join EU'. BBC News, 10 December 2012.

BBC News. 2012b. Scottish independence: 'Border checks' warning from home secretary. BBC News, 25 March 2012.

BBC News. 2012c. Scottish independence: Sir David Edward says Jose Manuel Barroso 'wrong' on EU. BBC News, 17 December 2012.

BBC News. 2013a. David Cameron speech: UK and the EU. BBC News, 23 January 2013. BBC News. 2013b. Theresa May says UK to keep European Arrest Warrant. BBC News, 9 July 2013.

Bieber, R. and Monar, J., eds., 1995. Justice and Home Affairs in the European Union: The Development of the Third Pillar. Brussels: European Interuniversity Press.

Bigo, D. et al., eds., 2010. Europe's 21st Century Challenge: Delivering Liberty. Farnham: Ashgate. 
Bossong, R., 2012. The Evolution of EU Counter-terrorism: European Security Policy after 9/11. London: Routledge.

Brady, H., 2013. Britain's 2014 justice opt-out: why it bodes ill for Cameron's EU strategy. London: Centre for European Reform.

Bulmer, S. et al., 2002. British Devolution and European Policy-making: Transforming Britain into Multi-level Governance. Basingstoke: Palgrave Macmillan.

Bures, O., 2011. EU Counterterrorism Policy: A Paper Tiger?. Farnham: Ashgate.

Cairney, P., 2006. Venue shift following devolution: when reserved meets devolved in Scotland. Regional and Federal Studies, 16 (4), 429-445.

Cairney, P., 2012. Understanding Public Policy: Theories and Issues. Basingstoke: Palgrave Macmillan.

Cameron, D., 2013. EU Speech at Bloomberg, 23 January 2013. Available from: https://www.gov.uk/government/speeches/eu-speech-at-bloomberg [Accessed 19 September 2013].

Conzelmann, T. and Smith, R., eds. 2008. Multi-level Governance in the European Union: Taking Stock and Looking Ahead. Baden-Baden: NOMOS.

Cram, L. (2014) When push comes to shove: context and continuity in Scotland-EU relations, Scottish Constitutional Futures Forum, 24 January. Available from: http://www.scottishconstitutionalfutures.org/OpinionandAnalysis/ViewBlogPost/tabid/1767/a $\underline{\text { rticleType/ArticleView/articleId/2912/Laura-Cram-When-Push-Comes-to-Shove-Context- }}$ and-Continuity-in-Scotland-EU-Relations.aspx [Accessed 1 February 2014].

Eckes, C., 2009. EU Counter-Terrorist Policies and Fundamental Rights: The Case of Individual Sanctions. Oxford: Oxford University Press.

Engel, A. and Parks, R., 2012. Accommodating an independent Scotland: how a British-style constitution for the EU could secure Scotland's future, Discussion paper. Brussels: European 
http://www.epc.eu/documents/uploads/pub_3017_scotland_s_future.pdf [Accessed 15 August 2013].

Eski, Y., McGuinness. P. and Burman, M., 2011. Changes to Scotland's Criminal Justice System Post-Devolution: Main legislative developments, major reviews of policy and procedure, and the introduction of 'new' bodies'. Glasgow: Scottish Centre for Crime and Justice Research. Available from: $\quad$ http://www.sccjr.ac.uk/wpcontent/uploads/2012/12/Changes-to-Criminal-Justice-in-Scotland-post-Devolution.pdf [Accessed 4 August 2013].

Fyfe, N. and Henry, A., 2012. Negotiating divergent tides of police reform within the United Kingdom. Journal of Police Studies, 25 (4), 171-190.

Geddes, A., 2000. Immigration and European Integration: Towards Fortress Europe? Manchester: Manchester University Press.

George, S., 1998. An Awkward Partner: Britain in the European Community. Oxford: Oxford University Press.

Guardian. 2011. Alex Salmond calls for Scotland to have greater influence in EU. Guardian, 18 May 2011.

Guardian. 2013. Scotland facing 'enormous' costs for independent security. Guardian, 28 January 2013.

Guardian, 2014a. It's the economy stupid: how Scotland's voters approach the independence vote. Guardian, 12 February 2014.

Guardian, 2014b. Independent Scotland 'would find it extremely difficult to join EU'. Guardian, 16 February 2014.

Guardian, 2014c. Theresa May would seek passport checks between Scotland and England. Guardian, 14 March 2014. 
Guild, E. and Geyer, F., eds., 2008. Security versus Justice? Police and Judicial Cooperation in the European Union. Aldershot: Ashgate.

Hinarejos, A., Spencer, J. R. and Peers, S., 2012. Opting out of EU criminal law: what is actually involved? CELS Working Paper, New Series, $n^{\circ} 1$. Cambridge: University of Cambridge.

Hix, S., 1994. The study of the European Community: the challenge to Comparative Politics. West European Politics, 17 (1), 1-30.

Home Office. 2013a. The JHA Opt-in Protocol and Schengen Opt-out Protocol, 11 June. Available from: https://www.gov.uk/government/uploads/system/uploads/attachment_data/file/206474/Final_ opt-in webpage update.pdf [Accessed 21 August 2013].

Home Office. 2013b. Third Annual Report to Parliament on the Application of Protocols 19 and 21 to the Treaty on European Union (TEU) and the Treaty on the Functioning of the European Union (TFEU) ("the Treaties") in Relation to EU Justice and Home Affairs (JHA) matters (1 December 2011 - 30 November 2012), April 2013. Available from: http://www.official-documents.gov.uk/document/cm85/8541/8541.pdf [Accessed 21 August 2013].

Hooghe, L. and Marks, G., 2001. Multi-level Governance and European Integration. Lanham, MD: Rowman \& Littlefield.

Hooghe, L. and Marks, G., 2010. Types of multi-level governance. In: H. Enderlein, S. Wälti and M. Zürn, eds. Handbook on Multi-level Governance. Cheltenham: Edward Elgar, 17-31. House of Commons Foreign Affairs Committee, 2013. Foreign policy considerations for the UK and Scotland in the event of Scotland becoming an independent country, Sixth Report of Session 2012-13, HC 643. London: Stationery Office. 
House of Lords European Union Committee, 2008. FRONTEX: The EU External Borders Agency, 9th Report of Session 2007-2008, HL Paper 60. London: Stationery Office.

Huysmans, J., 2006. The Politics of Insecurity: Fear, Migration and Asylum in the European Union. London: Routledge.

John, P., Bevan. S. and Jennings, W., 2011. The policy-opinion link and Institutional change: the legislative agenda of the UK and Scottish Parliaments. Journal of European Public Policy, 18 (7), 1052-1068.

Keating, M. et al. 2003. Does devolution make a difference? Legislative output and policy divergence in Scotland. Legislative Studies, 9 (3), 110-139.

Kaunert, C., 2005. The Area of Freedom, Security and Justice: the construction of a 'European public order'. European Security, 14 (4), 459-483.

Kaunert, C., 2007. 'Without the power of purse or sword': The European Arrest Warrant and the role of the Commission. Journal of European Integration, 29 (4), 387-404.

Kaunert, C. (2010a) The external dimension of EU counterterrorism relations: competences, interests, and institutions. Terrorism \& Political Violence, 22 (1), 41-61.

Kaunert C (2010b) Europol and EU counterterrorism: International security actorness in the external dimension, Studies in Conflict \& Terrorism, 33 (7), 652-671.

Kaunert, C. (2010c) European Internal Security: Towards Supranational Governance in the Area of Freedom, Security and Justice? Manchester: Manchester University Press.

Kaunert, C. and Della Giovanna, M., 2010. Post-9/11 EU counter-terrorist financing cooperation: differentiating supranational policy entrepreneurship by the Commission and the Council Secretariat. European Security, 19 (2), 275-295.

Kaunert, C., and Léonard, S., 2011. EU counterterrorism and the European Neighbourhood Policy: an appraisal of the Southern dimension. Terrorism \& Political Violence, 23 (2), 286309. 
Kaunert, C., Léonard, S. and MacKenzie, A., 2012. The social construction of an EU interest in counter-terrorism: US influence and internal struggles in the cases of SWIFT and PNR. European Security, 21 (4), 474-496.

Kaunert, C., Léonard, S. and Pawlak, P., eds., 2012. European Homeland Security: A European Strategy in the Making? London: Routledge.

Kaunert, C., and Zwolski, K., 2013. The EU as a Global Security Actor: A Comprehensive Analysis across CFSP and JHA. Basingstoke: Palgrave Macmillan.

Kelstrup, M., 2006. Denmark in the process of European integration: dilemmas, problems and perspectives. In: J.L. Cambell, J.A. Hall and O.K. Pedersen, eds., National Identity and the Varieties of Capitalism: The Danish Experience. Montreal: McGill-Queen's University Press.

Kohler-Koch, B., 1998. The Evolution and Transformation of European Governance. Vienna: Institute for Advanced Studies.

Kohler-Koch, B. and Larat, F. eds., 2009. European Multi-level Governance: Contrasting Images in National Research. Cheltenham: Edward Elgar.

Léonard, S. and Kaunert, C., 2012. Between a rock and a hard place? The European Union's financial sanctions against suspected terrorists, multilateralism and human rights. Cooperation and Conflict, 47 (4), 473-494.

Levi- Faur, D., ed., 2012. The Oxford Handbook of Governance. Oxford: Oxford University Press.

MacKenzie, A., Kaunert, C. and Léonard, S., 2013. EU counterterrorism and the Southern Mediterranean countries after the Arab Spring: new potential for cooperation? Democracy and Security, 9(1-2), 137-156.

Marks, G. and Hooghe, L., 2004. Contrasting visions of multi-level governance. In: I. Bache and M. Flinders, eds. Multi-level Governance. Oxford: Oxford University Press. 
Marks, G., 1993. Structural policy and multilevel governance in the EC. In: A. Cafruny and G. Rosenthal, eds. The State of the European Community. Boulder, CO: Lynne Rienner.

Miller, V., 2012. The UK's 2014 Jurisdiction Decision in EU Police and Criminal Justice Proposals, Standard Note SN/IA/6268. London: House of Commons Library.

Ministry of Justice and the Home Office. 2012. Report to Parliament on the Application of Protocols 19 and 21 to the Treaty on European Union (TEU) and the Treaty on the Functioning of the European Union (TFEU) ('the Treaties') in Relation to EU Justice and Home Affairs Matters (1 December 2010 - 30 November 2011). January.

Ministry of Justice and the Home Office. 2013. Third Annual Report to Parliament on the Application of Protocols 19 and 21 to the Treaty on European Union (TEU) and the Treaty on the Functioning of the European Union (TFEU) ("the Treaties") in Relation to EU Justice and Home Affairs (JHA) matters (1 December 2011 - 30 November 2012). April.

Palmer, R., 2008. Devolution, Asymmetry and Europe: Multi-level Governance in the United Kingdom. P.I.E.-Peter Lang: Brussels.

Peers, S., 2006. EU Justice and Home Affairs Law. $2^{\text {nd }}$ edition. Oxford: Oxford University Press.

Peers, S., 2012. EU Justice and Home Affairs Law. $3^{\text {rd }}$ edition. Oxford: Oxford University Press.

Richards, D. and Smith, M., eds. 2004. Governance and Public Policy in the UK. Oxford: Oxford University Press.

Ripoll Servent, A., 2010. Point of no return? The European Parliament after Lisbon and Stockholm. European Security, 19 (2), 191-207.

Ripoll Servent, A., 2011. Co-decision in the European Parliament: comparing rationalist and constructivist explanations of the 'Returns' Directive. Journal of Contemporary European Research, 7 (1), 3-22. 
Ripoll Servent, A., 2013. Holding the European Parliament responsible: policy shift in the Data Retention Directive from consultation to codecision. Journal of European Public Policy, 20 (7), 972-987.

Ripoll Servent, A. and MacKenzie, A., 2011. Is the EP Still a data protection champion? The Case of SWIFT. Perspectives on European Politics and Society, 12 (4), 390-406.

Ripoll Servent, A. and MacKenzie, A. 2012. The European Parliament as a 'norm taker'? EU-US relations after the SWIFT Agreement, European Foreign Affairs Review, 17 (Special Issue), 71-86.

Scotsman, 2014. Scottish independence: New poll shows yes shift. Scotsman, 23 March.

Scott, K., 2011. Politics and the police in Scotland: the impact of devolution. Crime, Law and Social Change, 55, 121-132.

Scottish Government. 2007. Choosing Scotland's Future: A National Conversation: Independence and Responsibility in the Modern World. Available from: http://www.scotland.gov.uk/Publications/2007/08/13103747/4 [Accessed 4 August 2013].

Scottish Government, 2009. Independent Review of Policing in Scotland. Available from: http://www.scotland.gov.uk/Resource/Doc/258103/0076554.pdf [Accessed 25 July 2013].

Scottish Government, 2011. Your Scotland, Your Future. Scottish National Party.

Scottish Government, 2012. Sewel Convention - Legislative Consent Motions. Available from: http://www.scotland.gov.uk/About/Government/Sewel [Accessed 24 July 2013].

Scottish Government, 2013a. Scottish Police Federation Annual Conference/Speeches. Available from: http://www.scotland.gov.uk/News/Speeches/Police-Scotland [Accessed 21 August 2013].

Scottish Government, 2013b. Scotland's Future: Your Guide to an Independent Scotland. Edinburgh: The Scottish Government.

Spence, D., ed. 2007. The European Union and Terrorism. London: John Harper. 
Stephenson, P., 2013. Twenty years of multi-level governance: 'where does it come from? What is it? Where is it going?, Journal of European Public Policy. 20(6), 817-837.

Trauner, F. and Carrapiço, H., 2012. The External Dimension of EU Justice and Home Affairs after the Lisbon Treaty: Analysing the Dynamics of Expansion and Diversification. Special Issue of European Foreign Affairs Review, 17 (5).

Uçarer, E., 2001. From the sidelines to centre stage: sidekick no more? The European Commission in Justice and Home Affairs, European Integration Online Papers (EIoP), 5 (5), $1-25$.

Usher, J., 1997. Variable geometry or concentric circles: patterns for the European Union. International and Comparative Law Quarterly. 46 (2), 243-273.

Van Munster, R., 2009. Securitizing Immigration: The Politics of Risk in the EU. Basingstoke: Palgrave Macmillan.

Walker, N., 2004. Europe's Area of Freedom, Security and Justice. Oxford: Oxford University Press.

Wallace, H., 1997. At odds with Europe. Political Studies, 45 (4), 677-688. 